\title{
The Impact of E-Commerce on Consumer Purchasing Behavior: The Mediating Role of Financial Technology
}

\author{
Rukana Alshweesh ${ }^{1}$, Dr. Srinivas Bandi ${ }^{2}$ \\ ${ }^{1}$ Research Scholar, ISBR Research Centre, Bangalore \\ ${ }^{2}$ Professor, Research Guide, ISBR Research Centre, Bangalore \\ Corresponding Author: Rukana Alshweesh
}

DOI: https://doi.org/10.52403/ijrr.20220261

\begin{abstract}
The study aimed to determine the impact of ecommerce on the consumer's purchasing behavior with the presence of financial technology as an intermediate variable in largescale food and consumer goods stores in Jordan, to achieve the goal of the study, the researcher relied on the descriptive and internal approach, an analytical approach, and the study sample consisted of all workers in large consumers and food stores in Jordan is within the high administrative levels, in addition to workers in IT departments, by (408) individuals, to whom the researcher distributed the study tool. Electronically, I used SPSS and AMOS to analyze the data and test hypotheses.

The study found a set of results, the most important of which is the high level of relative importance of e-commerce, consumer behavior and financial technology in large-scale consumers and foodstuff stores in Jordan, and the existence of a statistically significant ecommerce impact on consumer behavior, in addition to the fact that through mediation in fintech The effect of e-commerce on consumer behavior increased, and the mediation was partial.
\end{abstract}

The study recommended the necessity of continuing the large consumer and foodstuff stores in Jordan to enhance the dimensions of ecommerce by understanding these stores of their importance in order to increase efficiency and effectiveness and achieve the goals, by spreading awareness of e-commerce, as well as continuing to pay attention to and adopt financial technology because of its direct positive impact on consumer buying behavior.

Key Words: E-Commerce, Consumer Buying Behavior, Financial Technology

\section{INTRODUCTION}

Consumer desires and characteristics determine the parameters of a good marketing strategy in the modern era, making the consumer the cornerstone of successful marketing activity. As a result, one of the most important marketing activities in the organization is the study and analysis of consumer behavior, which has resulted from changes in the external environment due to the intensification of competition and the expansion of the size and type of alternatives available to the consumer on the one hand, and the change and diversity of his needs and desires on the other.

Consumer behavior research is a relatively new and complex field. It outlines and defines the pattern that the consumer follows in his behavior when searching for, purchasing, or evaluating the goods or services that he expects to satisfy his needs and desires.

The tremendous technological progress that the globe witnessed in the latter half of the twentieth century resulted in significant scientific and technological advancement. It also aided in the development of many modern apps and 
marketing operations, as well as having a big impact on the process of connecting businesses to electronic networks, resulting in a highly interconnected cell and changing the nature of all consumers' economic patterns. (Al-Kunduz, 2017).

The information and knowledge era is witnessing a huge transformation in information and communication technologies, which has resulted in a fundamental shift in the thinking patterns and behavior of both producers and consumers. One aspect of this metamorphosis is a shift in competitive rules, as well as work methods and means.

E-commerce is one of the most prominent and influential commercial revolutions, allowing it to become a dominant sector and activity in many advanced economies. (Bindaoudia and Mnawar, 2014).

The concept of e-commerce is constantly being updated and is always affected by modern technology. Ecommerce is regarded as one of the most significant global developments that has imposed itself strongly over the last ten years, and it has since become one of the pillars of the new economic system that focuses on the simultaneous use of the Internet and e-commerce. The Internet's emergence as one of the most important modern communication technologies has greatly aided the promotion and growth of e-commerce, and business organizations have recognized the value of e-commerce in increasing competitiveness, marketing products and services, and providing instant information to customers and consumers. (Chiao \& Connie, 2016).

On the other hand, the world today is witnessing a qualitative shift from the monetary to the non-monetary economy, owing to financial technology services that have been able to bring about fundamental changes in the financial services sector, where financial technology provides services to many individuals and businesses in quicker, easier, and less expensive ways than traditional means. Financial technology has the potential to make a significant contribution to financial stability, as well as to shape the future of financial activities and services. (Harfoush, 2019).

Financial technology (Fintech) refers to products and services that use technology to enhance the quality of traditional financial services. This technology is faster, cheaper, and easier to use, and a larger number of people may benefit from it; in most cases, these services and products are produced by startup enterprises. Fintech refers to any financial technology or innovation that results in a new business model, method, or product that affects financial markets and institutions. (Bin Alqama, 2018).

As Kaplan (2020) demonstrates, the most significant contribution of Fintech to global e-commerce is to change and improve the online payment system, particularly in countries where consumers do not have credit or debit cards or bank accounts, where (fin-tech) has introduced alternative payment methods. The introduction of payment services that interact with e-commerce platforms, such as Dwolla, Stripe, WePay, and BlueSnap, has increased the efficiency of e-commerce.

Based on the preceding, this study determined the impact of e-commerce on Jordanian customer purchasing behavior with the presence of financial technology as an intermediary variable.

\section{The study Problem}

The researcher noticed a shortfall in the investment of large-scale consumer and food stores in Jordan and the ability of Websites based on e-commerce to attract consumers and influence their purchasing decisions using financial technology by referring to a number of previous studies such as (Rahman et al, 2018) and being one of the website owners (Jopoints website).

Therefore, based on the foregoing, the study's problem becomes evident by addressing the main question: (What is the impact of e-commerce on consumer purchasing behaviour in large-sized 
consumer and food stores in Jordan with the availability of financial technology as an intermediate variable?)

\section{Study Questions}

This study seeks to answer the following questions:

1. What is the relative importance of ecommerce in Jordanian large-sized consumer and food stores in terms of its dimensions (consumer support information exchange - product evaluation)?

2. What is the relative importance of purchasing behavior in its dimensions (cognitive response - emotional response - purchase) in large-sized consumer and food stores in Jordan?

3. What is the relative importance of financial technology in electronic stores in Jordan?

4. What is the impact of e-commerce with its dimensions (consumer support information exchange - product evaluation) on consumer behavior in its combined dimensions (cognitive response - emotional response purchase) in large-sized consumer and food stores in Jordan?

5. What is the impact of e-commerce with its dimensions (consumer support information exchange - product evaluation) on financial technology in large-sized consumer and food stores in Jordan?

6. What is the impact of e-commerce with its dimensions (consumer support information exchange - product evaluation) on consumer behavior in all its dimensions (cognitive response emotional response - purchase) with the presence of financial technology as an intermediate variable in large-sized consumer and food stores in Jordan?

\section{Study hypotheses}

This study tests the following hypotheses:

H01: There is no statistically significant effect at the level of significance $(\alpha \leq 0.05)$ for e-commerce with its dimensions (consumer support - information exchange product evaluation) on consumer purchasing behavior with its combined dimensions (cognitive response - emotional response purchase) in large-sized consumer and food stores in Jordan.

$\mathrm{H} 02$ : There is no statistically significant effect at the level of significance $(\alpha \leq 0.05)$ for e-commerce with its dimensions (consumer support - information exchange product evaluation) on financial technology in large-sized consumer and food stores in Jordan.

H03: There is no statistically significant effect at the level of significance $(\alpha \leq 0.05)$ for financial technology on consumer purchasing behavior in large-sized consumer and food stores in Jordan.

H04: There is no statistically significant effect at the level of significance $(\alpha \leq 0.05)$ for e-commerce on consumer purchasing behavior in the presence of financial technology as a mediating variable in largesized consumer and food stores in Jordan.

\section{Study Objectives}

This study aims to identify the impact of e-commerce on consumer purchasing behavior with the presence of financial technology as an intermediary variable, through the following:

1- Indicating the level of relative importance of e-commerce in its dimensions (consumer support - information exchange - product evaluation) in large-sized consumer and food stores in Jordan.

2- Demonstrating the level of relative importance of consumer purchasing behavior in its dimensions (cognitive response - emotional response - purchase) in large-sized consumer and food stores in Jordan.

3- Indicating the level of relative importance of financial technology in electronic stores in Jordan.

4- Identifying the impact of e-commerce in its dimensions (consumer support information exchange - product evaluation) on consumer behavior in its combined 
Rukana Alshweesh et.al. The impact of e-commerce on consumer purchasing behavior: the mediating role of financial technology.

dimensions (cognitive response - emotional response - purchase) in large-sized consumer and food stores in Jordan.

5- Identifying the impact of e-commerce in its dimensions (consumer support information exchange - product evaluation) on financial technology in large-sized consumer and food stores in Jordan.

6- Verifying the impact of e-commerce in its dimensions (consumer support information exchange - product evaluation) on consumer behavior in its combined dimensions (cognitive response - emotional response - purchase) with the presence of financial technology as an intermediate variable in large-sized consumer and food stores in Jordan.

\section{Study model}

The following figure shows the study model for its independent variable represented in e-commerce and its dimensions (consumer support - information exchange - product evaluation), and its dependent variable represented in consumer behavior with its dimensions (cognitive response - emotional response - purchase), in addition to the mediating variable represented by financial technology, as follows:

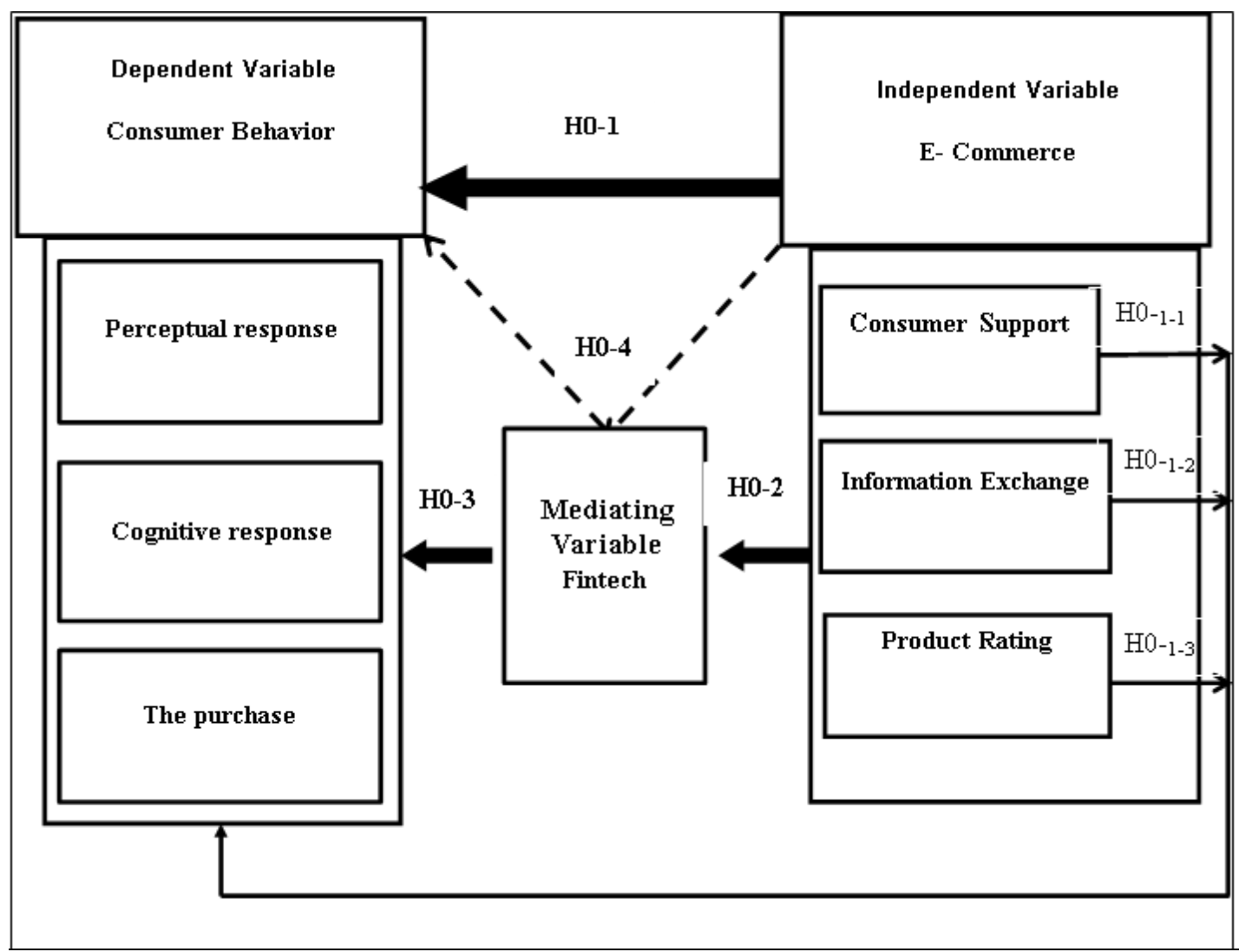

\section{E-Commerce}

E-commerce has many definitions, as Al-Hadiri (2018) indicated that ecommerce is a new concept that explains the process of buying and selling or exchanging products, services and information through computer networks, including the Internet, Salah (2016) defined it as: a set of integrated business processes that all institutions and individuals deal with and rely on electronic processing.
E-commerce is defined as: a means for the delivery of information, services or products via telephone lines, computer networks, or any electronic means (Salah, 2016). (Kumar \& Umakanth, 2018) indicated that e-commerce is the performance of a business process between business partners using advanced information technology, and it is also a set of digital transactions related to commercial activities between projects to each other, 
between projects and individuals, and between projects and management.

Qaid (2017) pointed out that ecommerce is commercial transactions based on the exchange of services between the parties related to the e-marketing process, and these parties are represented by companies, customers and government agencies, to meet the desires of companies to reduce service costs and increase efficiency, and the desire of consumers to obtain the service faster and more luxuriously alike, through the Internet, that is, without the need for them to be in a particular place or direct face-to-face contact.

Through e-commerce, everything related to the purchase, sale and delivery of goods is implemented digitally, through data and information that are inserted through communication networks and other global commercial networks.

\section{Consumer's behavior:}

(Loura, 2016) defined the consumer as: the person who buys or has the ability to purchase the goods and services offered for sale, with the aim of satisfying personal or family needs and desires.

The consumer is defined as: the one who uses products to satisfy human needs, whether the thing subject of consumption is perishable by one use, such as food, drink, and medicine, or it is perishable except by multiple, successive uses, through partial extinction, such as clothing and means of transportation. Ghattas, 2015).

Abbasi (2014) defined the consumer as: Every person who acquires or uses a good or service for a non-professional purpose, and in the sense of violating this definition, every person who acquires goods or services for his professional purposes is not considered a consumer, and scholars in this field touched upon the difference between the ordinary or traditional consumer and the electronic consumer. The consumer, while the electronic consumer is governed by the rules for customer protection by the laws regulating ecommerce (Abdul Karim, 2020).

Consumer behavior is defined (Ali 2015) as the process of purchasing items and services that individuals believe are valid in satisfying their needs and aspirations, thus they decide to purchase certain quantities of them at specified periods.

(Mansi, 2017) defines consumer behavior as the science through which individuals choose, buy and use goods, services, ideas and experiences to satisfy their needs and desires.

It is also possible to identify consumer behavior through direct observation of the actions, behaviors and movements of the consumer when making a purchase decision. It can also be identified through the procedures that take place within the individual that precede the decision-making process and cannot be seen. Therefore, it is of great interest to researchers in most times (Al-Qandour, 2017). Consumer's behavior through electronic means is almost the same as the consumer's behavior towards products in the traditional purchase process, the difference lies in the method used only, and not their behaviors per se (Qaid, 2017).

Electronic consumer behavior is an innate human behavior as a result of the desire to achieve a specific need, before it is classified as a consumer behavior, as this includes the purchase and use of goods and services via the Internet by watching electronic advertisements that have a noticeable impact on a large scale, and it shows a kind of satisfaction with goods, which is somewhat different from buying and consuming from the traditional market (Al-Harash, 2014).

\section{Financial technology (Fin-tech)}

Fin-tech is described as those products and services that rely on modern technologies to improve the quality of traditional financial services. This technology is faster, cheaper, easier and can be accessed by a larger number of 
individuals. In most cases, these services and products are developed by start-ups, and the financial technology sector rapid growth enables strong investment returns that support the path of economic development across the region, technology companies provide new solutions that the financial sector can employ to improve the efficiency and effectiveness of its operations (Harfoush, 2019).

Today, the world has witnessed a quantum leap from a monetary economy to a non-monetary economy, thanks to financial technology services, as it is able to bring about radical changes in the financial services sector, where financial technology provides services to many individuals and institutions in the fastest and least expensive way, compared to traditional means, which it can make a significant contribution to achieving financial stability, so the current stage is a critical stage for those who work in the financial services sector, due to the recent witness of this huge amount of technological innovations that have changed the way of doing business, transferring money, daily transactions, and the technology sector. Finance is one of the most important sectors that receive support from decision-makers around the world (Zainab and Al-Zahraa, 2018).

Fin-tech is generally defined as any technological invention that is employed in financial services, and these innovations have been used in this industry and have developed new technologies that compete with traditional financial markets ( $\mathrm{Abu}$ Karsh, 2019).

The word "Fin-tech" refers to the use of technology to provide financial solutions, as this term consists of two parts; "Technology," and "Finance." It means innovative start-ups that use technology to reconsider financial and banking services (Ben Alqamah, 2018).

\section{Previous studies}

The researcher has summarized a set of previous studies that are directly and indirectly related to the subject of the current study, and arranged them in chronological order from newest to oldest, as follows:

(Baabdullah, 2020), entitled: Factors Influencing Online Buying Behavior of Customers in Saudi Arabia

Aimed to identify the factors that may affect online purchase behavior of customers in Saudi Arabia, to achieve the goal of the study, the researcher adopted the descriptive approach to study the impact of various factors, relying on a cross sample of Saudi online shoppers with a total of (212) shoppers where the study questionnaire distributed among them.

(Liu et al, 2019), Online Cross Border E Commerce Consumer Behavior: A Case Study of Sino US Trade Conflicts.

This study aimed to identify how the trade disputes between China and the United States affect the consumer behavior of ecommerce via the Internet, and the work strategies for e-commerce via the Internet that were adopted to confront the SinoAmerican trade war. To achieve the objectives of the study, the researchers adopted the descriptive approach by analyzing E-commerce and business data for Chinese consumers. The results of the study showed that neither consumers' desire to consume, consumption capacity and consumer behavior patterns, nor business strategies and trade patterns were changed during this period of the Sino-US trade conflict.

\section{The study of Hajj Ali (2019), entitled: "The Impact of E-Commerce on Reducing Administrative Costs"}

The study aimed to identify the impact of electronic commerce in reducing administrative costs, to achieve the goal of the study, the researcher adopted the descriptive analytical approach, the study sample consisted of (92) female students from the community college at Khamis Mushait, Saudi Arabia. The study showed a set of results, the most important of which are: e-commerce helps the consumer to access the commodity at the lowest possible price, and it works to reduce the cost of 
sales for producers, and that there is a correlation and statistical significance between e-commerce and the reduction of administrative costs for business organizations.

Harfouche study (2019), entitled:

"Finance technology is a promising industry in the Arab world."

The study aimed to identify the concept of financial technology, its objectives and characteristics, most important services and fields, in addition to identifying the reality of financial technology in the Arab world, the volume of investments, as well as the difficulties and challenges facing this industry in the Arab world. To achieve the objectives of the study, the researcher adopted the descriptive approach by reviewing previous books and studies and information related to the subject of his study. The study reached a set of results, the most important of which are: Financial technology is a newly emerging sector, which would provide all kinds of traditional financial services, but in a different style and form, more developed, faster and more accurate, and that the countries of the world have made great strides in this field despite its modernity.

Pandey and Parmar study (Pandey \& Parmar, 2019), Factors Affecting Consumer's Online Shopping Buying Behavior.

The study aimed to identify the factors affecting consumer behavior in online shopping, to achieve the goal of the study, the researchers adopted the descriptive approach. The study sample consisted of (550) online shoppers in Kanpur-Indian, to whom a questionnaire was distributed. The results showed that online shopping behavior of consumers is influenced by several factors such as demographic factors, social factors, online shopping experience of consumers, knowledge of Internet and computer usage, website design, social media, situational factors, facilitation conditions and product, while characteristics, promotional scheme of sales, payment option, delivery of goods and product services influence After-sales service plays an important role in online shopping.

Bin Alqamah study (2018) entitled: "The Role of Financial Technology in Supporting the Banking and Financial Services Sector"

This study aimed to shed light on the concept of financial technology and its importance and how banks and financial technology companies benefit from the existing cooperation between them in the interest of both parties, with reference to the Bahraini experience. to achieve the objectives of the study, the researcher adopted the descriptive approach by referring to various sources and previous studies and international data and information on the subject Financial technology. The study concluded that financial technology offers many possibilities and advantages in relation to financial services and e-commerce, but an enabling environment must be provided, such as providing appropriate regulatory rules for the work of emerging companies in this field, in addition to information security and the provision of information and communication technology infrastructure. The development of financial technology also depends on the review of legal and supervisory frameworks, especially the clarity of laws related to the trading of digital financial products, and the management of risks that arise from emerging financial and banking products and services, using regulatory laboratories.

Liu and Zheng's study (Liu \& Zheng, 2018), entitled:Analysis of the Impact of Customer Trust on Consumers' Purchase Behavior Based on Online Shopping Platform: Taking Taobao Shop as an Example

This study aimed to identify the impact of some factors on the purchasing behavior of the consumer via the Internet. to achieve the goal of the study, the researchers adopted the descriptive analytical approach and the case study, and the study sample consisted of (90) 
consumers who deal with the (Taobao Shop) website in China. The study reached a set of results, the most important of which are: The most important factors affecting consumer buying behavior via the Internet are low prices, designing websites in an attractive way, and providing information about the commercial company.

Rahman et al. (Rahman et al., 2018) entitled: Consumer buying behavior towards online shopping: An empirical study on Dhaka city, Bangladesh

This study aimed to identify the most important factors affecting the purchasing behavior of consumers via the Internet. to achieve the goal of the study, the researchers adopted the descriptive analytical approach, and the study sample consisted of (160) consumers via the Internet in Dhaka - Bangladesh, and they were distributed to them the study tool represented by a questionnaire. The results of the study showed that the most influential factors on the purchasing behavior of the consumer via the Internet were home delivery and cash on delivery, and obtaining sufficient information about the product and the company, in addition to the security of the payment system.

Al-Kunduz study (2017) entitled: "Ecommerce and its role in consumer behavior: a field study.

The study aimed to know the relationship between the demographic variables (consumer type - consumer age consumer educational level - consumer social status - consumer income - consumer profession - family size) and the degree of shopping from e-commerce sites on the Internet. to achieve the goal of the study the researcher adopted the descriptive approach Analytical: The study sample consisted of (50) consumers shopping online in Misurata -Libyan. The study reached a set of results, the most important of which are: the absence of a statistically significant correlation between age, marital status, income, size of family members, and the extent of online shopping, meaning that all these variables did not affect the purchasing behavior of consumers.

\section{METHODOLOGY}

The study relied on the analytical descriptive approach, by describing the study variables represented by e-commerce, consumer purchasing behavior and financial technology, and analyzing the data collected from the study sample members in order to test the impact of e-commerce on consumer purchasing behavior and through the mediation of financial technology.

\section{The study population and its sample}

The study population consisted of all managers, chairmen and members of boards of directors in the retail sector (consumable and large-sized food stores) in Jordan, in addition to workers in the information technology (IT) departments in those stores, and their number was (467) male and female employees in (9) companies.

Table (1): Distribution of the study sample according to their personal and job data

\begin{tabular}{|l|l|l|l|}
\hline Variables & Categories & Repetition & ratio \\
\hline \multirow{5}{*}{ Sex } & Male & 271 & $\% 66.4$ \\
\cline { 2 - 4 } & female & 137 & $\% 33.6$ \\
\cline { 2 - 4 } & Total & 408 & $\% 100$ \\
\hline \multirow{5}{*}{ Qualification } & Diploma and less & 50 & $\% 12.3$ \\
\cline { 2 - 4 } & Bachelor & 193 & $\% 47.3$ \\
\cline { 2 - 4 } & M.A. & 117 & $\% 28.7$ \\
\cline { 2 - 4 } & PhD & 48 & $\% 11.8$ \\
\cline { 2 - 4 } & Total & 408 & $\% 100$ \\
\hline \multirow{5}{*}{ Income } & -25 & 33 & $\% 8.1$ \\
\cline { 2 - 4 } & $25-$ under 35 & 126 & $\% 30.9$ \\
\cline { 2 - 4 } & $35-$ less than 45 & 117 & $\% 28.7$ \\
\cline { 2 - 4 } & $45-$ less than 55 y & 79 & $\% 19.4$ \\
\cline { 2 - 4 } & +55 & 53 & 13.0 \\
\cline { 2 - 4 } & Total & 408 & $\% 100$ \\
\hline & Less than 1000 dinars & 137 & $\% 33.6$ \\
\cline { 2 - 4 } & $\begin{array}{l}\text { From 1000 - less than } \\
1500 \text { dinars }\end{array}$ & 81 & $\% 19.9$ \\
\cline { 2 - 4 } & $\begin{array}{l}\text { From 15000- Less than } \\
2000\end{array}$ & 77 & $\% 18.9$ \\
\cline { 2 - 4 } & $\begin{array}{l}\text { From 2000 dinars or } \\
\text { more }\end{array}$ & 113 & $\% 27.7$ \\
\cline { 2 - 4 } & Total & 408 & $\% 100$ \\
\hline
\end{tabular}

The study sample included all heads of boards of directors, managers and employees of information technology (IT) departments in large-sized consumer and food stores in Jordan, and due to the small size of the study population, the researcher followed the method of a comprehensive survey of all elements of the study community of (467) individuals, and a tool 
was distributed to them The study was conducted electronically through Google Drive, from which (408) valid questionnaires were retrieved for statistical analysis purposes, with a recovery rate of (87.5\%).In order to reach an accurate description of the characteristics of the study sample, frequencies and percentages were used, as the characteristics were represented in personal and occupational data represented by gender, educational level, age group and monthly income level. Table 1 shows the results of the analysis for these variables.

The data in Table No. (1) indicate that most of the study sample members were males, whose number reached (271), constituting $(66.4 \%)$, while females constituted only $(33.6 \%)$ and their number (137).

As for the scientific qualification, the percentage of those who hold a bachelor's degree constituted the highest percentage among other educational levels, reaching $(47.3 \%)$, followed by those who hold a master's degree, which amounted to $(28.7 \%)$, followed by those who hold diplomas and less, and a rate of $(12.3 \%)$. ), and finally those with a doctorate degree, as their percentage reached $(11.8 \%)$, which is the lowest percentage of those with an educational level in the study sample.

It is also noted that the age group whose ages ranged between (from 25 to less than 35 years) represented the highest percentage among the age groups in the sample by $(30.9 \%)$, while the age group (less than 25 years) constituted the lowest percentage among the sample members. The number of sample members within this category was (33) individuals, at a rate of $(8.1 \%)$.

With regard to the years of experience of the study sample members, the results of the analysis showed that the highest percentage in the sample had experience (15 years and more) with a percentage of $(45.9 \%)$, then those who had years of experience (5- less than 10 years), forming a percentage (27.4). \%), followed by those who have years of experience (less than 5 years) at a rate of $(17.2 \%)$, and finally the sample members who were in the experience category (10-less than 15 years) got $(9.6 \%)$, which is the lowest percentage.

As for the level of monthly income, the percentage of those whose income level is less than 1000 within the study sample was $(33.6 \%)$, which is the highest representative, followed by a category (from 2000 dinars and more) at a rate of $(27.7 \%)$, followed by a category (from 1000-1500 dinars), and at a rate of (19.9\%), followed in the last rank by the category (from 150002000 dinars) with a rate of $(18.9 \%)$.

\section{The validity of the study tool}

The structural validity of the study tool was verified, whereby this honesty means the extent to which the paragraphs of each of the study variables express the variable to which it belongs. Attention has been focused on ensuring that each variable of the study is accurately represented by a set of paragraphs or phrases appropriately, and that these paragraphs measure Indeed this variable, and the validity of the questionnaire content was measured by measuring the relationship between each paragraph and the axis to which it belongs and excluding paragraphs whose correlation coefficient is weak, and their statistical significance is at the level $(\alpha \leq 0.05)$, and as follows:

Table (2): The construction validity of e-commerce dimensions

\begin{tabular}{|l|l|l|}
\hline Dimension & R value & Sig. \\
\hline Consumer Support & 0.895 & $* * 0.000$ \\
\hline Information Exchange & 0.847 & $* * 0.000$ \\
\hline Product Evaluation & 0.933 & $* * 0.000$ \\
\hline
\end{tabular}

$$
\text { **Statistically significant at (less than 0.01) Level }
$$

From Table (2) it is clear that the correlation coefficients for the dimensions of e-commerce as an independent variable ranged between (0.847) and (0.933), and it is statistically significant at the level $(0.01)$, and this indicates a strong internal consistency for the dimensions of the independent variable (electronic commerce). 
Rukana Alshweesh et.al. The impact of e-commerce on consumer purchasing behavior: the mediating role of financial technology.

Table (3): The construction validity of the dimensions of consumer behavior

\begin{tabular}{|l|l|l|}
\hline Dimension & R value & Sig. \\
\hline cognitive response & 0.888 & $* * 0.000$ \\
\hline emotional response & 0.874 & $* * 0.000$ \\
\hline Purchasing & 0.862 & $* * 0.000$ \\
\hline \multicolumn{2}{|c|}{$*$ Statistically significant at (less than 0.01) Level }
\end{tabular}

Table (3) shows the correlation coefficients for consumer behavior dimensions as a dependent variable ranged between (0.826) and (0.888), which are statistically significant at $(0.01)$, indicating a strong internal consistency for the dimensions of the second axis (consumer behavior).

Table (4): third axis(financial technology) statements' validity

\begin{tabular}{|l|l|l|l|l|l|}
\hline Statement & R value & Sig. & Statement & R value & Sig. \\
\hline 1 & .6910 & $* * 0.00$ & 6 & .8110 & $* * 0.00$ \\
\hline 2 & 0.786 & $* * 0.00$ & 7 & 0.832 & $* * 0.00$ \\
\hline 3 & 0.701 & $* * 0.00$ & 8 & 0.777 & $* * 0.00$ \\
\hline 4 & 0.607 & $* * 0.00$ & 9 & 0.711 & $* * 0.00$ \\
\hline 5 & 0.671 & $* * 0.00$ & \multicolumn{5}{|l|}{} \\
\hline \multicolumn{7}{|l|}{ Statistically significant at (less than 0.01) Level } \\
\hline
\end{tabular}

Table (4) indicates the correlation coefficients for (financial technology) items ranged between (0.607) and (0.832), and statistically significant at the level (0.01), which indicates a strong internal consistency for the financial technology axis paragraphs.

\section{Stability of the study instrument:}

To ensure the stability of the study tool, the internal consistency was calculated according to Cronbach's alpha equation for all study variables, as follows:

\section{First - Stability of the first axis (e- commerce)}

The stability of the electronic dimensions was measured separately, and then the stability was measured for all the dimensions combined, according to the (Cronbach-Alpha) coefficient. The resolution paragraphs are considered to have internal consistency and stability, as the value of Cronbach's alpha coefficient reached $70 \%$ as a minimum. Table (5) shows the results of the stability test:

Table (5): Dimensions stability of the first axis (electronic commerce) using Cronbach's alpha coefficient $(n=408)$

\begin{tabular}{|l|l|l|}
\hline Dimension & Number of Statements & $\boldsymbol{\alpha}$ \\
\hline Consumer Support & 8 & 0.855 \\
\hline Information Exchange & 5 & 0.895 \\
\hline Product Evaluation & 3 & 0.906 \\
\hline E-Commerce Axis as a Whole & 16 & 0.951 \\
\hline
\end{tabular}

The results of Table (5) indicate that the Cronbach's alpha coefficient for all dimensions of the independent variable (electronic commerce) was (0.951), and the
Cronbach's alpha coefficients for each dimension of the first axis were high,

Where it reached (0.855) for consumer support, (0.895) for information exchange, and (0.906) for product evaluation.

based on the previously mentioned rule, all values were greater than $70 \%$, and this indicates that the paragraphs are stable. Second - The stability of the second axis (consumer behavior)

The stability was measured for the dimensions of the second axis (consumer behavior) separately, and then the stability was measured for each axis, according to the coefficient (Cronbach - Alpha). Table (6) shows the results of the stability:

Table (6) Dimensions stability of the second axis (consumer behavior) using Cronbach's alpha coefficient $(n=408)$

\begin{tabular}{|l|l|l|}
\hline Dimension & $\begin{array}{l}\text { Number } \\
\text { Statements }\end{array}$ & $\boldsymbol{\alpha}$ \\
\hline cognitive response & 6 & 0.885 \\
\hline emotional response & 5 & 0.844 \\
\hline Purchasing & 5 & 0.875 \\
\hline $\begin{array}{l}\text { consumer behavior axis as a } \\
\text { whole }\end{array}$ & 16 & 0.934 \\
\hline
\end{tabular}

According to the results of Table (6), the Cronbach's alpha coefficient for all dimensions of the second axis (consumer behavior) reached $(0.934),(0.885)$ for the cognitive response dimension, (0.844) for the emotional response dimension, and (0.875) for the purchase dimension, indicating stability based on the abovementioned rule. 
Third: The stability of the third axis (financial technology).

The stability of the paragraphs of the third axis (financial technology) was measured, according to the coefficient (Cronbach-Alpha). Table (7) shows the results of the stability, which amounted to (0.972), which indicates the existence of internal consistency between the paragraphs that measured the financial technology axis.

Table (7): third axis (financial technology) Dimensions stability using Cronbach's alpha coefficient $(n=408)$ \begin{tabular}{|l|l}
\hline Fin-Tech & Number of Statements \\
\hline
\end{tabular} Fin-Tech Axis as a whole 0.972

\section{Normality Distribution test}

The Kolmogorov-Smirnov (K-S) test was employed by the researcher to ensure that the data utilized for statistical analysis and hypothesis testing had a normal distribution.

Table (8): Normal distribution applying KolmogorovSmirnov(K-S) test

\begin{tabular}{|l|l|l|}
\hline Field & Test Value & Sig. \\
\hline Consumer Support & 0.109 & 0.202 \\
\hline Exchange of Information & 0.107 & 0.175 \\
\hline Product Rating & 0.085 & 0.158 \\
\hline Cognitive Response & 0.110 & 0.190 \\
\hline Emotional Response & 0.155 & 0.290 \\
\hline Purchasing & 0.102 & 0.255 \\
\hline Fin-Tech & 0.134 & 0.244 \\
\hline
\end{tabular}

Table (8) shows that the data for the current study followed the normal distribution approach, and showed that there were no statistical differences between the distribution of variable values and the values of the normal distribution at the level of significance $(\alpha \leq 0.05)$.

\section{Multi-Collinearity Test}

The researcher used the Variance Inflation Factor (VIF) and Tolerance test to verify the level of linear overlap between the dimensions of the independent variable.

Table (9): Multi-Collinearity Test results between independent variable's dimensions

\begin{tabular}{|l|l|l|}
\hline \multirow{2}{*}{ Variables } & \multicolumn{2}{|l|}{ Collinearity Statistics } \\
\cline { 2 - 3 } & VIF & Tolerance \\
\hline Consumer Support & 2.661 & 0.375 \\
\hline Exchange of information & 2.045 & 0.488 \\
\hline Product Rating & 1.221 & 0.891 \\
\hline
\end{tabular}

Table (9) shows that the values of the variance inflation factor (VIF) were all greater than (1) and less than (5), and the allowable variance values (Tolerance) were limited between (0.01) and (1), and this indicates that there is no There is a problem of linear correlation between the study variables.

Independence test results of the dimensions of the independent variable

Pearson correlation coefficients matrix was calculated to find out the relationship between the study variables, and to find out the suitability of the study model data for analysis, aiming to revealing the existence of a linear correlation problem between them. Table No. (10) shows the results of the correlation coefficients between the variables as follows:

\begin{tabular}{|c|c|c|c|c|c|c|c|}
\hline Variables & $\begin{array}{l}\text { Consumer } \\
\text { Support }\end{array}$ & $\begin{array}{l}\text { Exchange } \\
\text { Information }\end{array}$ & $\begin{array}{l}\text { Product } \\
\text { Rating }\end{array}$ & $\begin{array}{l}\text { Cognitive } \\
\text { Response } \\
\end{array}$ & $\begin{array}{l}\text { Emotional } \\
\text { Response }\end{array}$ & Purchasing & $\begin{array}{l}\text { Fin- } \\
\text { Tech }\end{array}$ \\
\hline $\begin{array}{l}\text { Consumer } \\
\text { Support }\end{array}$ & 1 & & & & & & \\
\hline $\begin{array}{l}\text { Exchange } \\
\text { Information }\end{array}$ & $0.675^{* *}$ & 1 & & & & & \\
\hline Product Rating & $0.763 * *$ & $.860 * * 0$ & 1 & & & & \\
\hline $\begin{array}{l}\text { Cognitive } \\
\text { Response }\end{array}$ & $0.667 * *$ & $0.381 * *$ & $0.566 * *$ & 1 & & & \\
\hline
\end{tabular}

It is clear from the results of Table (10) that most of the correlations between the dimensions of the study are statistically significant at $(\alpha \leq 0.05)$, and that the correlation values between the dimensions of the independent variable were less than (0.80), thus the data is judged that there is no complete correlation between the dimensions of the independent variable and the dimensions of the other variables (Hair, et al., 2010).

\section{Dimensions analysis}

To identify the estimates of the sample members who work in large-sized consumer and food stores, within the higher 
administrative levels, and in the information technology (IT) departments on the axes and dimensions of the study, the arithmetic means and standard deviations of their answers were calculated, and the results came as illustrated by the following tables:

\section{(E-Commerce) Independent Variable Dimensions}

The arithmetic means and standard deviations of the responses of the study sample members on the dimensions of ecommerce were extracted, Table No. (11)

Table (11): AM and RIS of the estimates of the sample members on the dimensions of e-commerce

\begin{tabular}{|l|l|l|l|l|}
\hline Rank & No. & Dimension & Am & RIS. \\
\hline 3 & 1 & Consumer Support & 3.60 & Mid. \\
\hline 1 & 2 & Information Exchange & 3.99 & High \\
\hline 2 & 3 & Product Evaluation & 3.82 & High \\
\hline E-commerce as a whole & 3.80 & High \\
\hline
\end{tabular}

The arithmetic means of the sample members' estimates of the relative importance of e-commerce ranged between (3.60 - 3.99), and after exchanging information, it came in first with the highest arithmetic average of (3.99), with a high relative importance, followed by product evaluation, with an arithmetic average of (3.82), with a high relative importance.

According to the data in the previous table, the arithmetic mean of the sample members' estimates on the dimensions of ecommerce as a whole was (3.80), indicating a high level of relative importance for ecommerce in large-scale consumer and food stores from the perspective of managers and workers in their information technology departments.

\section{Dimensions of the dependent variable (consumer behavior)}

The arithmetic means and standard deviations of the responses of the study sample members on the dimensions of consumer behavior were calculated, and Table No. (12) shows these results.

Table (12): AM and SD of the estimates of the sample members on consumer behavior dimensions' variable

\begin{tabular}{|c|c|c|c|c|}
\hline Rank & No. & Dimension & Am & RIS \\
\hline 2 & 1 & cognitive response & 3.96 & High \\
\hline 3 & 2 & emotional response & 3.72 & High \\
\hline 1 & 3 & purchasing & 3.99 & High \\
\hline \multicolumn{3}{|c|}{ Consumer behavior as a whole } & 3.80 & High \\
\hline
\end{tabular}

According to the data in Table (12), the arithmetic means of the sample members' estimates on the dimensions of consumer behavior ranged from (3.72 to 3.99), with after purchase having the highest arithmetic mean of (3.99) and a high relative importance. followed by the cognitive response, with an arithmetic mean It was (3.96), with high relative importance, followed by emotional response, with a mean of (3.72), and with high relative importance. According to the data in the previous table, the arithmetic mean of the sample members' estimates on the dimensions of consumer behavior as a whole was (3.89), which has a high relative importance.

\section{The mediating variable (fin -tech)}

The arithmetic means and standard deviations of the study sample members' replies on the mediating variable (financial technology) were calculated, and the findings are shown in Table No. 13.

Table (13): AM and SD of Fin-tech statements

\begin{tabular}{|l|l|l|l|l|l|}
\hline Rank & No & Statement & AM & SD & RIS \\
\hline 1 & 36 & Fin-tech provides faster payment methods for buying or selling via e-commerce & 4.05 & 0.65 & H \\
\hline 2 & 40 & $\begin{array}{l}\text { Fin-tech contributes to facilitating the access of services and products to consumers through e- } \\
\text { commerce }\end{array}$ & 4.03 & 0.61 & M \\
\hline 3 & 41 & The use of financial technology via e-commerce leads to better business development. & 4.03 & 0.66 & M \\
\hline 4 & 33 & Fin-tech facilitates efficient mechanisms for cross-border payments. & 3.98 & 0.69 & H \\
\hline 5 & 38 & Fin-tech provides innovative technological solutions in the field of financial services via e-commerce. & 3.97 & 0.64 & H \\
\hline 6 & 37 & $\begin{array}{l}\text { Fin-tech provides new money management services which improve financial planning for e- } \\
\text { commerce startups }\end{array}$ & 3.94 & 0.69 & H \\
\hline 7 & 34 & Fin-tech offers effective solutions to the problems of late payments. & 3.93 & 0.70 & H \\
\hline 8 & 39 & Fin-tech uses technologies in order to deliver products and services at the lowest cost to consumers. & 3.90 & 0.70 & H \\
\hline 9 & 35 & Fin-tech companies focus on user demand to design user-friendly products. & 3.85 & 0.66 & H \\
\hline
\end{tabular}


According to the data in Table 13, the statement (36) (financial technology provides faster payment methods for buying or selling through electronic commerce) ranked first with a high relative importance, with a mean (4.05), while the statement (35) (financial technology companies focus on user demand to design easy-to-use products) ranked last with a high relative importance, with a mean (4.05). (3.85).

\section{Hypothesis testing}

H01: There is no statistically significant effect at the level of significance $(\alpha \leq 0.05)$ for e-commerce with its dimensions (consumer support - information exchange product evaluation) on consumer purchasing behavior with its combined dimensions (perceptual response - emotional response purchase) in large consumer and food stores size in Jordan.

The researcher used standard multiple regression analysis to determine the impact of e-commerce dimensions (consumer support - information exchange product evaluation) on consumer purchasing behavior in large-sized consumer and food stores, as shown in Table (14).

Table 15

\begin{tabular}{|c|c|c|c|c|c|c|c|c|c|c|c|}
\hline Dependent Variable & $\begin{array}{l}\text { Model } \\
\text { Summ }\end{array}$ & & ANOVA & & & Coefficient & & & & & \\
\hline \multirow{4}{*}{$\begin{array}{l}\text { Consumer } \\
\text { Purchasing } \\
\text { Behavior }\end{array}$} & $\mathbf{R}$ & R2 & f & D.F & Sig f* & variable & $\beta$ & SE & B & $\mathbf{t}$ & Sig $t^{*}$ \\
\hline & \multirow[t]{3}{*}{0.756} & \multirow[t]{3}{*}{0.571} & \multirow[t]{3}{*}{164.321} & \multirow[t]{2}{*}{3} & \multirow[t]{3}{*}{0.00} & $\begin{array}{l}\text { Consumer } \\
\text { Support }\end{array}$ & 0.219 & 0.034 & 0.169 & 4.96 & 0.000 \\
\hline & & & & & & $\begin{array}{l}\text { Information } \\
\text { Exchange }\end{array}$ & 0.513 & 0.035 & 0.406 & 11.44 & 0.000 \\
\hline & & & & 404 & & $\begin{array}{l}\text { Product } \\
\text { Evaluation }\end{array}$ & 0.134 & 0.035 & 0.102 & 2.911 & 0.004 \\
\hline
\end{tabular}

*Statistically significant at the level of significance $(\alpha \leq 0.01)$

The results of Table (14) indicate that the correlation coefficient $(\mathrm{R}=0.756)$ indicates a positive and strong relationship between the independent variable and the dependent variable, and the effect of ecommerce dimensions on the dependent variable (consumer purchasing behavior) is a statistically significant effect, as the calculated F value was (164.321) and with a level of significance ( $\mathrm{Sig}=0.00)$, which is less than (0.05), as it appeared that the value of the coefficient of determination $(\mathrm{R} 2=$ $0.571)$, which indicates that $(57.1 \%)$ of the variance in (consumer purchasing behavior) can be explained by the variance in dimensions of e-commerce.

$s$ for the coefficients table, it showed that the value of $(\beta)$ at the dimension (consumer support) amounted to (0.219) and that the value of $\mathrm{T}$ at (4.96), with significance level of $(\mathrm{Sig}=0.00)$, which indicates that the effect of this dimension is significant, while the value of $\beta$ at (information exchange) dimension has reached (0.513), and T-value is (11.44) with a significance level of ( $\mathrm{sig}=0.00)$, which indicates that the effect of this dimension is significant. The value of $\beta$ at the (product evaluation) dimension is (0.134) and its Tvalue is (2.911) with significance level (Sig $=0.004$ ), which indicates that the effect of this dimension is significant. Through the indicated $\beta$ values, it is clear that the information exchange as one of the dimensions of e-commerce had the greatest impact on the purchasing behavior of the consumer, followed by the consumer support dimension, and then the product evaluation.

Based on the results, reject the first null hypothesis and accept the alternative hypothesis that says: There is a statistically significant effect at $(\alpha \leq 0.05)$ for ecommerce with its dimensions (consumer support - information exchange - product evaluation) on consumer purchasing behavior with its combined dimensions (Cognitive response - emotional response purchase) in large-sized consumer and food stores in Jordan.

H02: There is no statistically significant effect at $(\alpha \leq 0.05)$ for e-commerce with its dimensions (consumer support - information exchange - product evaluation) on financial 
Rukana Alshweesh et.al. The impact of e-commerce on consumer purchasing behavior: the mediating role of financial technology.

technology in large-sized consumer and food stores in Jordan. The researcher used multiple regression analysis to determine the impact of e-commerce dimensions (consumer support - information exchange product evaluation) on financial technology in large-sized consumer and food stores in Jordan, as shown in Table (15).

Table (15): Multiple regression analysis of the impact of e-commerce dimensions on Fin-tech

\begin{tabular}{|c|c|c|c|c|c|c|c|c|c|c|c|}
\hline \multirow{2}{*}{$\begin{array}{l}\text { Dependent Variable } \\
\text { Fin-tech }\end{array}$} & \multicolumn{2}{|c|}{ Model Summery } & \multicolumn{3}{|c|}{ ANOVA } & \multicolumn{6}{|l|}{ Coefficients } \\
\hline & $\mathbf{R}$ & $\mathbf{R 2}$ & $\mathbf{f}$ & D.F & Sig $\mathbf{f}^{*}$ & variable & $\beta$ & SE & $\mathbf{B}$ & $\mathbf{t}$ & Sig $t^{*}$ \\
\hline & 0.607 & 0.369 & 72.004 & 3 & 0.00 & Consumer support & 0.183 & 0.047 & 0.160 & 3.41 & 0.00 \\
\hline & & & & 404 & & Information exchange & 0.40 & 0.049 & 0.358 & 7.36 & 0.00 \\
\hline & & & & 407 & & Product rating & 0.115 & 0.048 & 0.099 & 2.06 & 0.04 \\
\hline
\end{tabular}

*Statistically significant at the level of significance $(\alpha \leq 0.01)$

Results of Table (15) indicate that the correlation coefficient $(\mathrm{R}=0.607)$ indicates positive relationship between the independent and dependent variable, and the impact of the independent variables (ecommerce dimensions) on the dependent variable (financial technology) is a statistically significant effect, where the value of Calculated F (72.004) with a significance level of ( $\mathrm{Sig}=0.00)$ which is less than (0.05), as it appeared that the value of the coefficient of determination $(\mathrm{R} 2=$ $0.369)$, which indicates that $(36.9 \%)$ of the variance in (financial technology) can be explained by the variance in (Dimensions of e-commerce).

As for the coefficients table, it showed that the value of $(\beta)$ at the dimension (consumer support) amounted to (0.183) and that the value of $\mathrm{T}$ at (3.41), with $(\mathrm{Sig}=0.00)$, which indicates that the effect of this dimension is significant, while the value of $\beta$ at The (information exchange) dimension has reached (0.40) and its T-value is (7.36) with a significance level of $(\mathrm{sig}=0.00)$, which indicates that the effect of this dimension is significant. The $\beta$-value at the (product evaluation) dimension is (0.115) and T-value is (2.06) at $(\mathrm{Sig}=0.04)$, which indicates that the effect of this dimension is significant.
Through the indicated $\beta$ values, it is clear that the exchange of information as one of the dimensions of e-commerce had the greatest impact on financial technology, followed by consumer support, and then product evaluation.

Results that have been reached reject the second main null hypothesis and accept the alternative hypothesis that says: There is a statistically significant effect at $(\alpha \leq 0.05)$ for e-commerce with its dimensions (consumer support - information exchange product evaluation) in financial technology in material stores consumer and food large scale in Jordan.

H03: There is no statistically significant effect at the level of significance $(\alpha \leq 0.05)$ for financial technology on consumer purchasing behavior in large-sized consumer and food stores in Jordan.

The researcher used simple regression analysis to determine the impact of financial technology on consumer purchasing behavior in large-sized consumer and food stores in Jordan. The results of the hypothesis test are shown in Table (16), which shows the value of the regression coefficient $(ß)$, the value of $(T)$, and the level of significance.

Table (16): Results of a simple regression test for the impact of financial technology on consumer behavior

\begin{tabular}{|l|l|l|l|l|l|l|l|l|l|l|l|}
\hline Dependent Variable & Model summery & ANOVA & Coefficient & D.F & Sig f* & variable & $\beta$ & SE & B & t & Sig t* \\
\hline Consumer purchasing behavior & R & R2 & f & D.F & (n) \\
\cline { 2 - 9 } & 0.698 & 0.487 & 384.59 & 1 & 0.698 & Fin-tech & 0.698 & 0.031 & 0.616 & 19.611 & 0.000 \\
\hline
\end{tabular}

Table (16) shows that the value of $(\mathrm{R}=0.698)$, indicating that there is a strong association between financial technology and consumer behavior (69.8\%). 
The result of the coefficient of determination appears to be $(\mathrm{R} 2=0.487)$, indicating that financial technology has explained $(48.7 \%)$ of the variance in customer behavior.

The value of $(\mathrm{F})$ reached (384.59) at the level of significance ( $\operatorname{sig}=0.000$ ) in the coefficients table, confirming the significance of the regression at the level (0.05) and one degree of freedom.

The transactions table also shows that the value of $(\beta=0.698)$, that is, the change in one unit in (financial technology) leads to a change of $(69.8 \%)$ in the dependent variable (consumer behavior), and that the value of $(\mathrm{T}=19.611)$ is at a level of significance ( $\mathrm{sig}=0.000$ ) and this confirms the significance of the coefficient at the level $((\leq 0.05)$.

The third null hypothesis was rejected, and the alternative hypothesis was accepted, which states: Financial technology has a statistically significant effect on customer purchasing behavior at large-scale consumer and food stores in Jordan at the level of significance (0.05).

H04: There is no statistically significant effect at the level of significance $(\alpha \leq 0.05)$ for e-commerce on consumer purchasing behavior in the presence of financial technology as a mediating variable in largesized consumer and food stores in Jordan.

To test this hypothesis, the AMOS analysis program was used, based on the Path Analysis test, and the suitability of the selected model, and Table No. (17) shows the results of this test.

Table (17): Values of fitness Indexes for the trajectories model

\begin{tabular}{|l|l|l|}
\hline Fit Index & $\begin{array}{l}\text { Index } \\
\text { Value }\end{array}$ & $\begin{array}{l}\text { Fit Index Sig. } \\
\text { Value }\end{array}$ \\
\hline Chi square (Chi2). & 9.31 & function \\
\hline Degrees of freedom (df). & 4 & --- \\
\hline indication & 0.000 & function \\
\hline $\begin{array}{l}\text { Chi-square (Chi2)/degrees of } \\
\text { freedom (df) }\end{array}$ & 2.327 & less than 3 \\
\hline Limits of Trust (RMSEA) & 0.058 & less than 0.08 \\
\hline Incremental Fit Index (IFI) & 0.96 & 0.95 \\
\hline Non-Standard Fit Index (NNFI) & 0.95 & 0.95 \\
\hline Comparative Fit Index (CFI) & 0.97 & 0.95 \\
\hline Model Quality Standard (GFI) & 0.95 & greater than 0.90 \\
\hline
\end{tabular}

The model fit is acceptable, as evidenced by the values of the incremental fit index (IFI), comparative fit index (CFI), and non-standard fit index being high and at or above the acceptable limits, and the confidence limits index (RMSEA) recording a low value of (0.057), and the confidence limits not exceeding the value that indicates the quality (Bian, 2011).

After confirming the suitability of the proposed pathways model to test the fourth main hypothesis, the pathways were tested for the study variables, and the results came as shown in Table (18).

Table (18): Results of path analysis to show the direct and indirect impact of e-commerce on consumer purchasing behavior through Fin-tech mediation

\begin{tabular}{|c|c|c|c|c|}
\hline \multicolumn{3}{|c|}{ Path $\longrightarrow$} & Std. value & Sig. \\
\hline Consumer Support & \multicolumn{2}{|c|}{ consumer's behaviour } & 0.586 & $* * 0.000$ \\
\hline Exchange of information & \multicolumn{2}{|c|}{ consumer's behaviour } & 0.59 & $* * 0.000$ \\
\hline Product Rating & \multicolumn{2}{|c|}{ consumer's behaviour } & 0.62 & $* * 0.000$ \\
\hline E-Commerce & \multicolumn{2}{|c|}{ consumer's behaviour } & 0.63 & $* * 0.000$ \\
\hline \multicolumn{3}{|l|}{ Indirect impact } & \multirow[t]{2}{*}{ Std. value } & \multirow[t]{2}{*}{ Sig } \\
\hline \multicolumn{3}{|l|}{ Path- } & & \\
\hline Consumer Support & Fin-tech & consumer's behaviour & 0.76 & $* * 0.000$ \\
\hline Exchange of information & Fin-tech & consumer's behaviour & 0.68 & $* * 0.000$ \\
\hline Product Rating & Fin-tech & consumer's behaviour & 0.71 & $* * 0.000$ \\
\hline E-Commerce & Fin-tech & consumer's behaviour & 0.82 & $* * 0.000$ \\
\hline
\end{tabular}

The direct connection between the dimensions of e-commerce and customer behavior in large-sized consumer and food stores in Jordan was substantial, as shown in Table (18), and it is statistically significant at the level (0.01).

The effect values between the dimensions of e-commerce and consumer behavior in large-scale consumer and food stores in Jordan with the existence of an indirect influence (the median variable) financial technology were similarly strong, and it is statistically significant at the level of the table (0.01). When comparing the direct impact of e-commerce dimensions to the indirect impact of e-commerce 
dimensions, it was discovered that the impact values with the existence of financial technology as an intermediary element all increased.

This indicates that financial technology as an intermediary variable has a positive impact on the direct effect between the dimensions of e-commerce, as this variable (the mediator) has clearly raised the values of the effect and the mediation was partial, because the effect between the dimensions of e-commerce and consumer behavior remained statistically significant in the effect. Indirect (Bian, 2011), which means rejecting the fourth null hypothesis, and accepting the alternative hypothesis that says:

There is a statistically significant effect at a significant level $(\alpha \leq 0.05)$ of ecommerce on consumer purchasing behavior with the presence of financial technology as a mediating variable in largesized consumer and food stores in Jordan.

\section{DISCUSS THE RESULTS}

\section{First - Discussing the dimensions of e- commerce:}

The results of the study indicated that the relative importance of the dimensions of the independent variable (electronic commerce) was generally high, except for the dimension (consumer support), where it came after (information exchange) in the first place with the highest arithmetic average of (3.99), and with a high relative importance, followed by the dimension (product evaluation), with a mean of (3.82), of high relative importance, followed by (consumer support), with a mean of (3.60), and of medium relative importance, and this indicates the interest of large-sized consumer and food stores in the subject of e-commerce.

The researcher explains this result by realizing managers and workers in information technology departments of the importance of e-commerce, as e-commerce effectively contributes to finding multiple options for the product or service in front of consumers who choose what suits them, and they also emphasized that e-commerce enables business organizations to manufacturing its products or providing its services to a wide range of consumers according to their desires and needs at the lowest possible cost, as e-commerce interacts with consumers and answers their inquiries, and works to collect their opinions on the goods and services provided, forming a general idea of their desires, interests and needs? Which contributes to the improvement of those services and products according to those desires and needs.

The researcher attributes the result of the (interchange of information) dimension obtaining the greatest relative importance as one of the dimensions of (electronic commerce) to the awareness of business organizations in general and largesized consumer and food stores and stores to the importance of information in ecommerce, through the exchange of good information about the products or services of a company the consumer will have a positive mental image of that company, which will contribute to increasing the sales of these companies, and the process of exchanging information contributes to evaluating the product, and thus the consumer becomes aware of the multiple options that are clear to him through ecommerce, so he chooses the most appropriate ones.

This result agreed with Hajj Ali (2019), which showed that e-commerce helps the consumer to access the commodity at the lowest possible price, and also reduces the cost of sales for producers.

\section{Second - Discussing the dimensions of consumer behavior:}

The results revealed that the relative importance of the dimensions of consumer behavior was high, with a mean of (3.89), with the dimension of (purchasing) coming in first with the highest arithmetic mean of (3.99), and of high relative importance, followed by the dimension of (perceptual response), with an average of (3.72), and of high relative importance. 
The researcher attributes this result to consumers' realization of the importance of e-commerce, as the use of e-commerce for various means of attraction targeting the final consumer plays a significant role in his response to the products and services provided through them, in addition to the Norwegian and marketing strategies directed to the consumer through ecommerce play an important and essential role.

The researcher also explains this finding by stating that consumers save time and effort when shopping for and purchasing products and services through ecommerce because e-commerce provides them with a wide range of options and trade-offs in terms of quality and price, as well as the fact that the information provided through e-commerce about products and services is well-established in the marketplace.

This result matched with the findings of Qaid (2017), who found a high level of emotional and cognitive response among consumers to electronic promotions, as well as the findings of Pandey and Barmer, who found that consumers' online shopping behavior is influenced by a variety of factors. Demographic factors, social factors, consumer online shopping experience, internet and computer knowledge, website design, social media, situational factors, facilitation conditions, product characteristics, sales promotion scheme, payment option, merchandise delivery, and after-sales services all play a role in online shopping.

\section{Third - Discussing the results of the financial technology paragraphs.}

The study's findings show that the relative importance of the paragraphs of the mediating variable (financial technology) was generally high, with an average of (3.81), because most managers and owners of large-sized food and consumer stores, as well as their employees in IT departments, agreed on the importance of financial technology.
The researcher explains this result by simply stating that financial technology facilitates the access of services and products to consumers via e-commerce, and that using financial technology through ecommerce leads to better business development because it provides technological solutions that are innovative in the field of financial technology.

This result was consistent with the findings of the Harfouche study (2019), which found that financial technology is a newly emerging sector that will provide all types of traditional financial services in a new style and form that is more advanced, faster, and more accurate, and that countries around the world have made significant progress. Despite its newness, this field has a lot of potential, also agreed with the findings of Bin Alqamah's (2018) study, which demonstrated that financial technology provides a plethora of benefits and opportunities in the realms of financial services and e-commerce.

\section{The results of the analysis of the study hypotheses}

The results of the first hypothesis:

The results of the first main hypothesis revealed that e-commerce has a statistically significant effect on consumer behavior across all dimensions, with a coefficient of determination of (0.571) and high regression values for all dimensions, and a level of statistical significance of less than (0.05), indicating that the study sample consisted of store managers. Customer and food items are huge in size, and staff in IT departments are watching to observe how ecommerce affects consumer purchase behavior.

This result, according to the researcher, is due to the fact that ecommerce and its effective strategies attract consumers to the products and services provided through it, and that e-commerce allows consumers to clarify the features, specifications, and prices of products and services for alternative options, which positively influences their behavior toward 
purchasing those products and services. Consumers are more confident when purchasing through e-commerce because the basics and methods of information and personal data protection are used.

The researcher explains this finding by saying that the consumer's reliance on recommendations and advice from reference groups about an electronic service via multiple Internet channels pushes him to buy via e-commerce, in addition to the consumer's taste and needs evolving on a regular basis as a result of changes in the offered products and their prices.

This finding is consistent with Liu and Zheng's (Liu \& Zheng, 2018) findings, which found that low prices, attractive website design, and presenting information about the commercial company are the most impactful factors on consumer buying behavior via the Internet.

This result also agreed with Selvaraju and Karthikeyan (2016), whose results showed that easy access to products through the shopping website 24/7 makes the consumer feel more comfortable, which affects his positive behavior towards goods and products and purchase decision-making , The study also found that risks and product characteristics have a significant impact on a customer's intent to make a purchase decision, and that improving customer service by quickly responding to customer questions and dealing with customer inquiries and complaints would improve the retailer's brand image on the Internet, influencing their behavior and purchasing decisions.

The current study's findings contrasted from those of Gupta and Jain (2017), who found that customers have various security worries in online transactions and do not feel secure when shopping online, which negatively affects their purchasing behavior and attributes. Because of the differences in prevailing cultures regarding the use of e-commerce and the safety of its use, as well as the differences in the environments in which the current and previous studies were conducted, the researcher differed from the results of his current study with the results of his previous study.

\section{The results of the second main hypothesis:}

The study's findings revealed that ecommerce, in all of its dimensions (consumer support, information exchange, and product evaluation), has an impact on financial technology in Jordan's large consumer and food stores, with the model's explanatory power reaching $(\mathrm{R} 2=0.369)$, explaining $36.9 \%$ of the variance in the dependent variable (fin-tech).

This result is explained by the close relationship between e-commerce and financial technology, because the Internet is the foundation of commercial dealing in ecommerce, as well as the foundation for financial technology and its practice, and in order for the purchasing process through ecommerce to obtain goods and products and pay for them to be integrative, it is necessary to harness technological resources. As a result of the financial technology supplied by electronic financial services, electronic transactions through ecommerce lead to a rise in financial transactions.

\section{The results of the third main hypothesis:}

The results of the study showed a statistically significant effect at the level $(\alpha \leq 0.05)$ of financial technology on consumer purchasing behavior in largesized consumer and food stores in Jordan, as the explanatory power of the model reached $(\mathrm{R} 2=0.487)$, explaining its amount $(48.7 \%)$. of the variance in the dependent variable (consumer purchasing behavior).

The study explains that financial technology's services and solutions, particularly when it comes to paying for goods made through e-commerce, made it easier for consumers to make payments, which influenced their favorable buying behavior. 


\section{The results of the fourth main hypothesis}

With the presence of an indirect influence (financial technology) as an intermediary component, the value of the effect between e-commerce and consumer purchasing behavior rose, This implies that financial technology as an intermediary variable had a beneficial impact on the direct impact of e-commerce on customer behavior, as this variable (intermediary) enhanced the effect's values, and this effect was statistically significant, therefore there is a statistically significant effect at the level of significance $(\alpha \leq 0.05)$ for e-commerce with its dimensions (consumer support information exchange - product evaluation) on consumer behavior through financial technology as an intermediate variable.

This finding explains how financial technology helps to facilitate the processes of buying and selling products and goods in general, and consumers buying via ecommerce in particular, by providing electronic financial solutions and electronic payment systems, which increases the positive impact of e-commerce on consumer purchasing behavior. In addition, Fin-tech businesses are providing novel payment methods and platforms that have aided customers in conducting online transactions, resulting in a rise in financial inclusion and the bringing together of sellers and consumers.

\section{Recommendations}

Based on the results of this study, the researcher put forward a number of recommendations, as follows:

1. Recommending large-scale consumer and food stores in Jordan to continue enhancing the dimensions of $\mathrm{e}$ commerce by spreading awareness of ecommerce and gaining a better knowledge of their value in order to boost efficiency and effectiveness and achieve goals.

2. Enhancing the trend of large-scale consumer and food stores in Jordan to keep up with global developments in this field, particularly in developed countries, and to respond to all segments of consumers from their needs, requirements, preferences, and desires, through diversification of local, Arab, and foreign products, and customer involvement through their opinions and suggestions.

3. The continuation of large-sized consumer and food stores in Jordan. Interest in and adoption of financial technology because of its direct positive impact on consumer purchasing behavior.

4. Develop delivery services for largesized consumer and food stores in Jordan through electronic networks to reach all consumers, especially the elderly and people with special needs, and this is done by developing special tools and methods for this service and reviewing the experiences of developed countries and best practices in this field .

5. Creating platforms to share and exchange knowledge between largescale consumer and food stores in Jordan and suppliers, and share this information within databases to promote e-commerce and influence consumer purchasing behavior.

\section{Acknowledgement: None}

\section{Conflict of Interest: None}

\section{Source of Funding: None}

\section{REFERENCES}

1. Abbasi, Bu Obeid. (2014). The concept of the consumer in light of the preliminary work of the consumer protection project, Moroccan Journal of Economics and Comparative Law, (7) 31, 122-139.

2. Abdel Karim, Orani (2020). The impact of electronic tourism marketing on the behavior of the modern tourist consumer, Al-Bashaer Economic Journal, 1(6), 577591

3. Abdel Mohsen, Tawfiq Mohammed (2004). Marketing and E-Commerce Challenges, Arab Thought House, Cairo, Egypt. 
4. Abu Karsh, Sherif (2019). The New Era of FinTech, Journal of Banking and Financial Studies, 1(27), 8-12.

5. Abu Seif, Imad (2011). Consumer Behavior and Service Institution, University Publications Office, Algeria.

6. Al-Ghadeer, Hamad Rashid. (2011 AD). Factors affecting Jordanian consumer loyalty to brands of shopping goods, a field study in the Greater Amman Municipality, Yarmouk University Journal, 20(40), 322361.

7. Al-Hajj Ali, Abeer (2019). The impact of electronic commerce on reducing administrative costs, Journal of Business and Financial Economics, (3), 172-189.

8. Al-Harash, Abdullah (2014), The Role of Sales Activation Programs in Influencing the Negative Consumer Behavior of the Consumer, Al-Wahat Journal for Research and Studies, (7)2, 122-134.

9. Al-Hudayri, Khaled (2018). E-commerce and its impact on reducing marketing costs: a case study on the Libyana mobile phone company, Al-Jami Journal, 28, 184-208.

10. Ali, Alaa Abbas. (2015). Consumer loyalty how to achieve and maintain it, 3rd Edition, University House, Alexandria, Egypt.

11. Al-Qunduz, Amna Muhammad (2017). Ecommerce and its role in consumer behavior: a field study, Journal of Communication Research, 1(1), 148-181.

12. Baabdullah, A, (2020). Factors Influencing Online Buying Behavior of Customers in Saudi Arabia, Journal of Economic Administrative and Legal Sciences, (4)6, 146-159.

13. Bendaoudia, Wahiba and Munawwar, Usrir (2014). E-commerce as a tool to compete in global markets: a case study of the Arab countries, Journal of Globalization and North African Economics, 5(3), 1-20.

14. Bian, H. (2011). Structural Equation Modelling with AMOS II. Office For Faculty Excellence.

15. Bin Alqamah, Malika (2018). The role of financial technology in supporting the financial and banking services sector, AlIjtihad Journal for Legal and Economic Studies, (7)3, 86-107.

16. Chiao-yun, \& Connie, chang (2016). How Price influences online consumer decisionmaking, Coventry University, Japanese Journal of Administrative science, (22) 3, 245-254.
17. Ghattas, Nabih. (2015). A Dictionary of Terms of Economics, Finance and Business Administration, Library of Lebanon, Beirut.

18. Gupta, N, and Jain, R. (26 March 2017). Consumer Behavior Towards E- Commerce: Online Shopping, $3^{\text {rd }}$ International Conference on Recent Development in Engineering Science, Humanities and Management, Chandigarh, India.

19. Hair, J. F .. Jr. , Black, W. C. , Babin , B. J. \& Anderson, R. E. ( 2010 ). Multivariate data analysis : A global perspective (7th ed). Upper Saddle River, New Jersey: Pearson Education International

20. Harfoush, Saida (2019). Financial technology is a promising industry in the Arab world, Horizons Scientific Journal, 11(20), 724-744.

21. Imam, Muhammad Mahmoud (2018). The role of financial technology in developing the performance of Islamic banks, an article published on the Islam Online website, https://islamonline.net/18476, entry date (10/17/2020).

22. Kaplan, Marcia. (2020). How Does Fintech Affect Ecommerce?, article on Practical Ecommerce, (https://www.practicalecommerce.com/howdoes-fintech-affect-ecommerce), (22/11/2020).

23. Kumar, S., and Umakanth, S. (2018). Influence of E-Commerce on Buying Behaviour of Customers, International Journal of Economic and Business Review, (6) $9,5-12$.

24. Lee, J., and Lee, J. N. (2009). Understanding the Product Information Inference Process in Electronic WordofMouth: An Objectivity Subjectivity Dichotomy Perspective. Information and Management, 46(5):302-311.

25. Liu, L., Luo, W., Lin,J. and Huang, Y. (2019).Online Cross-Border E-commerce Consumer Behavior: A Case Study of SinoUS Trade Conflicts, Journal of Economics, Business and Management, (7)4, 174-181.

26. Liu, X., and Zheng, W. (2018). Analysis of the Impact of Customer Trust on Consumers' Purchase Behavior Based on Online Shopping Platform: Taking Taobao Shop as an Example, Advances in Social Science, Education and Humanities Research, (20)221, 369-372 
Rukana Alshweesh et.al. The impact of e-commerce on consumer purchasing behavior: the mediating role of financial technology.

27. Loura A.. (2016). Consumer Behavior for Dummies, Wiley publishing, Inc, Indianapolis, Indiana.

28. Mansi, Abdel-Aty. (2017). The effect of perceived and actual mental image components on the degree of Egyptian consumer loyalty to Egyptian products compared to their foreign counterparts, Journal of Finance and Trade, Suez University, 22 (7), 117-133.

29. Obeidat, Muhammad. (2013). Principles of Marketing, House of Culture for Publishing and Distribution, Amman, Jordan.

30. Pandey, A., and Parmar, J.(January 5, 2019) Factors Affecting Consumer's Online Shopping Buying Behavior, Proceedings of 10th International Conference on Digital Strategies for Organizational Success, Available at SSRN: https://ssrn.com/abstract=3308689 or http://dx.doi.org/10.2139/ssrn.3308689.

31. Qaid, Ibrahim (2017). Electronic promotion and its role in influencing consumer behavior towards products offered by economic institutions, $\mathrm{PhD}$ thesis, Faculty of Economics and Commercial Sciences, Kasdi Merbah University, Ouargla, Algeria.

32. Rahman, M., Islam, A., Esha, B., Sultana, N., and Chakravorty, S. (2018). Consumer buying behavior towards online shopping: An empirical study on Dhaka city, Bangladesh, Cogent Business \& Management, (1)5, 1-22.
33. Rameh, Jalal (2016). Patterns of Consumer Behavior: Theory and Practice, 6th Edition, Dar Ghaly for Publishing and Distribution, Algeria.

34. Rattanawicha, P., and Esichaikul, V. (2005). What Makes Websites Trustworthy? A Two-phase Empirical Study. Int. J. Electronic Business, 3(2): 110-136.

35. Salah, Fadi (2016). Introduction to ECommerce, Dar Al-Bidaa for Publishing and Distribution, Beirut, Lebanon.

36. Selvaraju, K., and Karthikeyan, P. (2016). Impact on E-Commerce towards Online Shopping and Customer Buying Behavior, Asian Journal of Research in Social Sciences and Humanities, (6)7, 1260-1270.

37. Wirtz, B.W., Schilke, O. and Ullrich, S. (2010). Strategic Development of Business Models: Implications of the Web 2.0 for Creating Value on the Internet. Long Range Planning, 43(2-3): 272-290.

38. Zainab, Hamad and Zahraa, Oqasem (2018). Basic Concepts of Financial Technology, Al-Ijtihad Journal for Legal and Economic Studies, 8(1), 400-415.

How to cite this article: Rukana Alshweesh, Srinivas Bandi. The impact of e-commerce on consumer purchasing behavior: the mediating role of financial technology. International Journal of Research and Review. 2022; 9(2): 479-499. DOI: https://doi.org/10.52403/ijrr. 20220261 